\title{
Projeto Acompanhando o Acompanhante
}

\author{
Araujo, Karina Albino do Nascimento; Nunes, Lorena Massi \\ Associacao Congregacao de Santa Catarina — projetosocial@hec.org.br
}

Este projeto visa acompanhar os acompanhantes e familiares dos pacientes a fim de contribuir com a rotina dos mesmos e melhorar a qualidade de sua permanência no Hospital. OBJETIVOS ESPECIFICOS: Prestar atendimento psíquico e social aos acompanhantes e familiares; orientar os mesmos quanto aos cuidados importantes com o enfermo e, seus direitos e deveres; promover palestras e oficinas sobre temas diversos; criar espaço de conversa para acolher suas dúvidas, dificuldades e sofrimentos; reduzir conflito entre família e Usuário e Instituição; debater a questão do que é ser Acompanhante. Metodologia utilizada neste projeto são realizadas reuniões com grupos de acompanhante para atingir os objetivos acima com a participação direta da equipe da equipe multidisciplinar (Assistentes Sociais, Psicólogos, Enfermeiros, Serviço de atendimento o usuário. Todas as demandas apresentadas pelo grupo de acompanhante serão identificadas e na medida do possível serão encaminhadas aos setores e/ou profissional competente, e tentaremos dar resolutividade às questões apresentadas pelo grupo de Acompanhante. Utilizaremos recursos audiovisuais, dinâmicas de grupo com o objetivo de amenizar as dificuldades que é ter alguém internado em hospital, muitas das vezes por um longo período. RESULTADOS ESPERADOS: Melhoria do atendimento prestado ao acompanhante e paciente internado; Melhoria da comunicação entre hospital e o acompanhante/ paciente; Diminuição do índice de reclamações por parte dos acompanhantes/ pacientes; Contribuir para a garantia dos direitos e deveres dos Acompanhantes. Concluímos que segundo a Política Nacional de Humanização o acompanhante "é o representante da rede social da pessoa internada que a acompanha durante toda a sua permanência nos ambientes de assistência a saúde". e em consonância ao Código de Ética do Serviço Social, no artigo $5^{\circ}$, a prática educacional contribui para a mudança, ampliação e percepção ampliada da população usuária dos serviços oferecidos. Partimos do pressuposto de que as pessoas fazem parte de sistemas complexos e interconectados que abarcam os fatores individuais, familiares e extra familiares, os amigos, a escola, o trabalho e a comunidade. Nessa concepção ecológica, um membro da família (da rede social) presente configura-se essencial não só para acompanhar a pessoa internada, mas também para ser orientado no seu papel de cuidador leigo. na visão ampliada de saúde, cuidar é um conceito abrangente que, para além dos tratamentos biomédicos, aponta para a criação de um ambiente relacional que permita à pessoa doente ou hospitalizada a descoberta ou a releitura do sentido e do valor de sua existência para aqueles que a rodeiam e para si mesma. o cuidado gera segurança e confiança; possibilita que a pessoa reencontre e manifeste a sua vitalidade, favorecendo a eficácia dos tratamentos. Remeter a pessoa a esse estado é o principal objetivo do cuidar. Daremos destaque a coresponsabilidade desses familiares pelo cuidado dos pacientes, dentro e fora da Unidade Hospitalar. Desse modo, acolher e acompanhar o acompanhante/cuidador, é importante por que? para melhor captar os dados do contexto de vida do doente e do momento existencial por ele vivido, possibilitando um diagnóstico abrangente; para ajudar na identificação das necessidades do doente e, do acompanhante durante o período em que esta no Hospital; para incluir, desde o início da internação, a comunidade no processo dos cuidados com a pessoa doente, aumentando a autonomia desta e de seus cuidadores; para equipe orientar os membros da família quanto ao seu papel de cuidadores leigos, que podem aprender algumas técnicas para a continuidade do cuidado em casa. para contribuir com a criação de espírito cooperativo e participativo de forma ativa e responsável entre os envolvidos no processo de internação, isto é, Colaboradores, Acompanhantes, Familiares e Pacientes do Hospital Estadual Central. Porque os acompanhantes ficam muito tempo no Hospital e sofrem junto com os Pacientes. por isso, precisam de um espaço para falar, ser escutado, tirar suas dúvidas e receber esclarecimentos de todo o contexto do processo de internação Hospitalar.

Araujo, Karina Albino do Nascimento; Nunes, Lorena Massi. Projeto Acompanhando o Acompanhante. In: Anais do Congresso Internacional de Humanidades \& Humanização em Saúde [= Blucher Medical Proceedings, num.2, vol.1]. São Paulo: Editora Blucher, 2014. ISSN 2357-7282

DOI 10.5151/medpro-cihhs-10664 